Marek Potkány

PhD, Associate Professor of the Department of Business Economics, Faculty of Wood Sciences and Technology, Technical University in Zvolen (Zvolen, Slovak Republic),

Lucia Krajčírová,

PhD, Assistant Professor of the Department of Business Economics, Faculty of Wood Sciences and Technology, Technical University in Zvolen (Zvolen, Slovak Republic);

Miloš Hitka,

PhD, Associate Professor of the Department of Business Economics, Faculty of Wood Sciences and Technology, Technical University in Zvolen (Zvolen, Slovak Republic),

Silvia Lorincová,

PhD, Assistant Professor of the Department of Business Economics, Faculty of Wood Sciences and Technology, Technical University in Zvolen (Zvolen, Slovak Republic)

\title{
INNOVATIONS OF THE CALCULATION METHODOLOGY ACCORDING TO MODIFIED DIMENSIONAL REQUIREMENTS FOR SELECTED PRODUCTION ${ }^{1}$
}

The main purpose of this article is to present the proposal of an innovative approach to optimizing the calculation methodology in the conditions of specific furniture production - single beds. The proposal presented is based on the results of actual research of the anthropometric measurements of the Slovak adult population, which indicate the trend of changes and the following modified dimensional requirements for the production. Our review of available scientific proposals for innovative calculation methodology proved the need for potential of concept of the variable costing at the base of cost classification to variable and fixed items according to capacity using. The practical imperfections of the information provided in the absorption costing system and its general rigidities was the reason of the application selected methodology. The authors proposed an alternative for calculation methodology by the determination of overheads rates and delimitation individual level of contribution margin.

Keywords: calculation, contribution margin, bed furniture dimensions, ergonomics, secular trends, innovation.

DOI: 10.21272/mmi.2017.4-28

Formulation of the problem. A person, especially its size and power capabilities, is a primary factor when designing and assessing the arrangement of workplaces, when producing the ergonomically correct working tools, machinery and furniture. The design of optimal workplace (furniture, working tools, etc.) is always based on measurements of the target sampling unit which is compared to the data of the whole population living in a certain area, usually broken down into men and women. Population data are detected usually on the sample at a certain point in time. They may change over a longer time from various reasons (such as the way of nutrition of the population, lifestyle, etc.). In addition to changes in time, important anthropometric characteristics may vary secularly and in space. It is related to the characteristics of the human population living in certain space. Secular trend refers to the tendency in increasing of the body size of successive generations compared to the previous generations. The final state is evaluated and not the speed with which the final state was reached. The main purpose of this article is to present the proposal of an innovative approach to optimizing the calculation methodology in the conditions of specific furniture production - single beds. The proposal presented is based on the results of actual research of the anthropometric measurements of the Slovak adult population, which indicate the trend of changes and the following modified dimensional requirements for the production. This innovative approach offers more exact information for management at the decision making tasks, as in strategic as well as

${ }^{1}$ This research was supported by project APVV-16-0297 - Updating of anthropometric database of Slovak population, project VEGA No. 1/0320/17 - Economic and Social Context of European 20/20/20 Targets from the Viewpoint of Economy Low-energy Houses and project IPA No. 15/2017 - Wooden houses and their potential in terms of tightened conditions of energy performance buildings. 
operational management systems.

Analysis of recent researches and publications. Secular trends were confirmed by various researches like [1-4]. Monitoring of secular trends has a practical importance in production of footwear, clothes, as well as in production of furniture. Hajn [5] argues that secular changes, whether positive or negative, are the result of interaction between genetic predisposition and environmental factors. This interaction is reflected in the present time as the impact of different living conditions in the various social groups, and long-term effects of gradual changes in living conditions. The researches of Vignerová, et al. [6], Jelačić, et al. [7] and Jirkovský [8] aimed at anthropometric dimensions of children and adult populations clearly show long-term changes in body dimensions. According to Vignerová [9] level of nutrition, health, psycho-sociological factors and socio-economic conditions in which the individual grows up are the factors that influence individual body height. Old castles are the evidence of the existence of secular trends. Most of today's girls need to bow in the door $[5,10]$. Changing the anthropometric parameters of an adult population affects the technical dimensions of bed furniture.

Based on previous research by authors Hitka, et al. [11] it can be stated that the dimensional quantities of the Slovak adult population after the age of maturity from the point of view of the growth process have increased statistically significantly by about $4.5-5 \%$ since the last measurements in 1987. Based on the current statistical characteristics of the physical dimensions of the current adult population of Slovakia (Table 1), it was possible to determine the dimensions of a single bed (Table 2) corresponding to this population [11].

Table 1 - Basic descriptive characteristics of the male population (developed by authors based on [11])

\begin{tabular}{|l|r|r|r|r|r|r|}
\hline \multirow{2}{*}{ Anthropometric character } & \multicolumn{4}{|c|}{ The original population } & \multicolumn{3}{|c|}{ Current population } \\
\cline { 2 - 7 } & \multicolumn{1}{|c|}{$\bar{x}$} & \multicolumn{1}{|c|}{$S_{x}$} & \multicolumn{1}{c|}{$S_{x \%}$} & \multicolumn{1}{c|}{} & \multicolumn{1}{c|}{$S_{x}$} & \multicolumn{1}{c}{$S_{x}$} \\
\hline Body height in standing & 174.1 & 6.5 & 3.7 & 182.1 & 6.6 & 3.6 \\
\hline Shoulder width (Bialtoid) & 44.7 & 2.5 & 5.7 & 48.3 & 4.4 & 9.2 \\
\hline
\end{tabular}

Table 2 - Length, width and height of the bed derived from the current size of population (developed by authors based on [11])

\begin{tabular}{|l|c|c|c|}
\hline Bed location & Final length of the lying area $(\mathrm{cm})$ & The final width of the lying area $(\mathrm{cm})$ & Final bed height $(\mathrm{cm})$ \\
\hline Apartment & 220.5 & 102.3 & 45.7 \\
\hline
\end{tabular}

Wood as a material is used in the production of bed furniture. It affects the price of the product therefore furniture companies should adjust pricing calculations [12-14]. Teplická, et al. [15] and Myšková [16] conclude that products are cost-bearing. Costs that are included in the calculation should be resolved in time so that only the costs associated with the performance are attributed to the products [17]. Product costs are monitored in calculation in the overall amount and in more detailed structure. From this point of view, unit direct costs can be distinguished to the unit direct costs that were generated by the products produced immediate (technological costs) and in essence, they are mostly direct costs. Overheads incurred by the operations of the manufacturing centre and other centres of company securing the overall activity of the enterprise are called indirect costs. Macík [18] denominates method when all the cost components are absorbed by individual performance as the absorption costing. It is difficult to define the universal calculation formula for all products, because companies compile calculation formulas according to their specific conditions of offered products. On the other side Popesko [19] says that in principle, the calculation formulas are in practice characterized by fixed structure and do not allow the use of various application and accommodation to different decision tasks.

If we assume that company has centre of production, supply centre, administration centre and sales centre, in designing of the calculation formula we present following general structure. By other 
organizational structure the calculation formula can be modified adequately. In our case study we use different allocation bases according to their causal relation to overheads. So we are operating, as Poniščiaková [20] states, with the so called differentiated overheads costing.

Table 3 - General calculation formula (developed by authors based on [19-21])

\begin{tabular}{|c|c|l|}
\hline 1. & + & Direct (technological) material \\
\hline 2. & + & Direct (technological) wages \\
\hline 3. & + & Other direct costs \\
\hline & $=$ & Direct (technological) costs \\
\hline 4. & + & Supply overhead costs \\
\hline $5 a$. & + & Production (technological) overhead costs \\
\hline $5 b$. & + & Production (general) overhead costs \\
\hline & $=$ & Production costs \\
\hline 6. & + & Administration overhead costs \\
\hline & $=$ & Product costs \\
\hline 7. & + & Sales overhead costs \\
\hline & $=$ & Total costs \\
\hline
\end{tabular}

In the items above the change in dimensions of bed furniture leads to a direct increase in 1 - direct (technological) material in the form of increased consumption of production material, of 2 - direct (technological) wages linked to time (when the time required for manufacturing changes), in 3 , if the field is attached to direct wages in the form of statutory deductions, health and social insurance paid by employer, in areas 4, 5, 6 and 7 relating to overheads by assuming that the allocation base for their conversion to calculation unit is one of the earlier mentioned items of the calculation formula. This formula includes all the costs, so therefore we talk about the absorption costing, as the Poniščiaková [20] states.

Basic material. Basic hygiene, health requirements and product safety belong to the ergonomic aspects in production of furniture. Müller [22] and Hajdu, et al. [23] argues that designers and engineers have to comply the requirements when designing the furniture. They need to know the anthropometry and ergonomics in relation to bed furniture. The principle of ergonomic aspects of the bed furniture, when it is produced, is based on respect for human anthropometric dimensions. It is because of a man is a basic scale to determines dimensional solution of the bed furniture [24-25]. Rubínová [26] states that an average human body cannot be crucial in dimensional solutions of bed furniture. Such bed furniture would fit only the people with physical dimensions either directly or nearby respond to the average dimension.

However, the needs of the remaining people would not be sufficiently respected, so it is not possible to rely on the average values (50\% quantile). But $95 \%$ quantile must be respected in the case of dimensional solutions of bed furniture. Poštúlková [27] states that bed furniture must meet a number of requirements in the field of anthropology, physiology and hygiene. The dimensions of bed furniture are standardized today. In Europe, a single bed can acquire dimensions of $200 \times 90 \mathrm{~cm}$ or $200 \times 100 \mathrm{~cm}$.

At present, in the Slovak Republic, there is no current unified basis for the application of anthropometric data in designing of product of daily consumption - Slovak Technical Standard in accordance with European Standard STN EN 547-3 + A1 "Safety of Machines. Dimensions of the human body - Part 3: Anthropometric Data" can help in the production of product of daily consumption [28]. Producers' efforts to optimize and rationalize product standards must be based on the knowledge of the current statistical properties of the user's physical dimensions.

Aim of the article. The aim of the paper is to point out the necessity of a change in the cost structure and calculation methodology using the calculation formula in the production of bed furniture due to the secular trend of the anthropometric dimensions of the Slovak adult population.

The main results of the study. In order to exactly calculate the final production cost of single bed, we started with the calculation formula, to which we have methodically added the profit margin calculation. In the 
М. Поткани, Л.Крайчірова, М.Гітка, С. Лорінцова. Інновації методології розрахунків відповідно до змінених розмірними вимогами до окремої продукції

first phase it was necessary to determine direct costs associated with production of single bed. In the calculation of direct material, we assumed that the production of single bed with dimensions $200 \times 90 \mathrm{~cm}$, the $4.38 \mathrm{~m}^{2}$ of direct material is needed. The unit price of direct material was fixed at the level $3.69 € /$ unit. When dimensions of bed increase to the value of $220.5 \times 102.3 \mathrm{~cm}$, total consumption of direct (technological) material increases to the level of $6.67 \mathrm{~m}^{2}$, representing an increase of $52.29 \%$. Wages directly related to the production of this product represents $2.91 €$ per $0.661 \mathrm{SH}$ (standard hour). After consultation with experts, we concluded that with the increased dimension of bed direct wages will change, because of the increase in labour input. Based on expert assumption this will increase the time needed for material treatment from 0.661 to $0.759 \mathrm{SH}$, which in percentage terms represents an increase of $14.78 \%$. For complete production of the entire single bed the total of 79 pieces of pins, cover caps and other support material with the total value of $0.96 €$ is needed. Here the increase is not expected. Subsequently summing up of the first three items we receive the amount of direct (technological) costs. Those, by the original dimensions of single bed $(200 \times 90$ $\mathrm{cm}$ ), would amount to $20.03 €$ and with the increased dimensions to $28.97 €$. The percentage increcement in item direct (technological) costs is $44.33 \%$ (Table 4).

Table 4 - Bed price calculation with initial and new dimensions (authors' development)

\begin{tabular}{|c|c|c|c|c|c|}
\hline & \multicolumn{2}{|c|}{$\begin{array}{l}\text { Initial dimensions } \\
200 \times 90 \mathrm{~cm}\end{array}$} & \multicolumn{2}{|c|}{$\begin{array}{c}\text { New dimensions of construction } \\
220.5 \times 102.3 \mathrm{~cm} \\
\end{array}$} & \multirow{2}{*}{$\begin{array}{c}\% \\
\text { of the change }\end{array}$} \\
\hline & $\begin{array}{l}\text { Calculation } \\
\text { data }\end{array}$ & $€$ & Calculation data & $€$ & \\
\hline Direct (technological) material & $4.38 \mathrm{~m}^{2}$ & 16.16 & $6.67 \mathrm{~m}^{2}$ & 24.61 & $52.29 \%$ \\
\hline Direct (technological) wages & $0,661 \mathrm{Nh}$ & 2.91 & $0,759 \mathrm{Nh}$ & 3.34 & $14.78 \%$ \\
\hline Other direct (technological) costs & & 0.96 & & 0.96 & $0.00 \%$ \\
\hline$\sum$ Direct costs & & 20.03 & & 28.91 & $44.33 \%$ \\
\hline Supply overhead costs & $100 \%$ & 20.03 & $100 \%$ & 28.91 & $44.33 \%$ \\
\hline Production (technological) overheads & $3.50 € / \mathrm{SH}$ & 2.31 & $3.50 € / \mathrm{SH}$ & 2.66 & $15.15 \%$ \\
\hline Production (general) overheads & $50 \%$ & 1.46 & $50 \%$ & 1.67 & $14.38 \%$ \\
\hline Production costs & & 43.83 & & 62.15 & $41.80 \%$ \\
\hline Administration overheads & $70 \%$ & 30.68 & $70 \%$ & 43.51 & $41.82 \%$ \\
\hline Product costs & & 74.51 & & 105.66 & $41.81 \%$ \\
\hline Sales overhead costs & $30 \%$ & 13.15 & $30 \%$ & 18.65 & $41.84 \%$ \\
\hline Total costs & & 87.66 & & 124.31 & $41.81 \%$ \\
\hline Profit 15\% & & 13.15 & & 18,65 & $41.83 \%$ \\
\hline Price & & 100.81 & & 142.96 & $41.81 \%$ \\
\hline
\end{tabular}

Production (technological) overheads are based on the calculation of the overhead rate, which compares the ratio of overheads and allocation base in time units - standard hours. Their amount can be detected even before production. For this reason the mentioned overheads were fixed at $3.5 € / \mathrm{SH}$.

Indirect costs in the production (general) overheads, supply overheads costs, administration overheads and sales overhead costs were allocated by overhead rates. The allocation base for production (general) overheads were direct wages, because they are directly dependent on the large share of human labour. The direct (technological) costs were determining for the calculation of supply overheads costs. Production costs as allocation base were determined for the calculation of administration and sales overheads. The specific percentages of the rates are presented in Table 4 . We assume that the determined values of overhead rates remain unchanged despite the change in the consumption of direct (technological) material and direct (technological) wages. The total costs are increased by $41.81 \%$ due to the higher consumption of direct material and direct wages. The calculation formula is further complemented by profit margin, which remained at the level of 15\% Return on Costs - ROS.

So the price of single bed is $100.81 €$ excluding VAT. In the case of dimension increase of single bed to $220.5 \times 102.3 \mathrm{~cm}$ we can say that due to this change the selling price determined by the general calculation formula will increase by $41.81 \%$. This assume, that only the consumption of direct 
(technological) material and direct (technological) wages increase by the other variables unchanged, but with fixation of level for individual overheads rates. In this case we have to state that such processed calculation does not provide exact information about the amount of costs. This calculation formula provides information about the amount of individual costs necessary for the construction of product. But from the managerial perspective this information is insufficient for decision making. It would be useful to define individual items in terms of fixed and variable costs. By classification analysis, according Scholleová [29], these items are identified by their specific behaviour and position in company based on past experience.

Popesko [19] stated that in practice, there are situations when the price of product is not made only as a total cost surcharge, but it is also influenced by competitive environment. In such case the company has to accept the market price of product and that price becomes a basis for determination of the cost of product. Then are the costs of product characterized and calculated as difference value between the price of product and expected profit. In this case we are talking about differential or also retrograde calculation. The author also considers that to not allocate the still increasing proportion of fixed costs ( $\mathrm{FC}$ ) of product was a logical reaction to the worsening of traditional direct costing precision. Synek, et al. [30] argues that in traditional direct costing the same rates (tariff) is used, even when volume of products changes. This leads to inaccurate allocation of overheads costs.

For more precise allocation of overhead costs, it is necessary to calculate new rates for modified volumes of production. This is so-called dynamic calculation. According Ponišciaková [20] it retains information base of general calculation formula, but has more explanatory power that answers the question of how costs affect the changes in volume of production in various phases. The author also states that thanks to this calculation it can be possible to determine the costs for the different degree of capacity utilization. The obtained information can then be used for decision making.

By the expert assessment for the individual overheads costs has allocated fixed and variable costs as follows. Variable costs (VC) were $68 \%$, of items of supply overheads, $43 \%$ of production (general) overheads and $37 \%$ of sales overhead costs. The remaining values were fixed component of costs. Based on this values of general calculation formula of type (Table 5) were recalculated.

Table 5 - Calculation of single bed with variable costs definition (authors' development)

\begin{tabular}{|c|c|c|c|c|c|c|c|c|}
\hline \multirow{3}{*}{$\begin{array}{l} \\
\text { Direct (technological) } \\
\text { material }\end{array}$} & \multirow{3}{*}{$\begin{array}{c}\begin{array}{c}\text { Calculation } \\
\text { data }\end{array} \\
4.38 \mathrm{~m}^{2}\end{array}$} & \multicolumn{2}{|c|}{$\begin{array}{c}\text { Initial } \\
\text { dimensions } \\
200 \times 90 \mathrm{~cm}\end{array}$} & \multirow{3}{*}{$\begin{array}{r}\begin{array}{c}\text { Calculation } \\
\text { data }\end{array} \\
6.67 \mathrm{~m}^{2}\end{array}$} & \multicolumn{2}{|c|}{$\begin{array}{l}\text { New dimensions of } \\
\text { construction } \\
220.5 \times 102.3 \mathrm{~cm}\end{array}$} & \multirow{2}{*}{\multicolumn{2}{|c|}{$\begin{array}{c}\% \\
\text { of Change }\end{array}$}} \\
\hline & & \multirow{2}{*}{\begin{tabular}{|l|}
$\mathrm{VC}$ \\
16.16
\end{tabular}} & \multirow[t]{2}{*}{ FC } & & \multirow{2}{*}{$\begin{array}{l}\text { VC } \\
24.61\end{array}$} & \multirow[t]{2}{*}{ FC } & & \\
\hline & & & & & & & $52.9 \%$ & \\
\hline $\begin{array}{l}\text { Direct (technological) } \\
\text { wages }\end{array}$ & & 2.91 & & & 3.34 & & $14.78 \%$ & \\
\hline $\begin{array}{l}\text { Other direct } \\
\text { (technological) costs }\end{array}$ & & 0.96 & & & 0.96 & & $0.00 \%$ & \\
\hline$\sum$ Direct costs & & 20.03 & & & 28.91 & & $44.33 \%$ & \\
\hline Supply overhead costs & $100 \%$ & 13.62 & 6.41 & $68 \%$ & 19.66 & 6.41 & $44.33 \%$ & $0.00 \%$ \\
\hline $\begin{array}{l}\text { Production (technological) } \\
\text { overheads }\end{array}$ & $3.50 € / \mathrm{SH}$ & 2.31 & & & 2.66 & & $15.15 \%$ & \\
\hline $\begin{array}{l}\text { Production (general) } \\
\text { overheads }\end{array}$ & $50 \%$ & 0.63 & 0.83 & $21.6 \%$ & 0.72 & 0.83 & $14.38 \%$ & $0.00 \%$ \\
\hline Production costs & & 36.59 & 7.24 & & 51.95 & 7.24 & $41.98 \%$ & $0.00 \%$ \\
\hline Administration overheads & $70 \%$ & & 30.69 & $423.7 \%$ & & 30.69 & & $0.00 \%$ \\
\hline Product costs & & 36.59 & 37.93 & & 51.95 & 37.93 & $41.98 \%$ & $0.00 \%$ \\
\hline Sales overhead costs & $30 \%$ & 4.87 & 8.28 & $13.3 \%$ & 6.91 & 8.28 & $42.00 \%$ & $0.00 \%$ \\
\hline \multirow{2}{*}{ Total costs } & & 41.46 & 46.21 & & 58.86 & 46.21 & $41.97 \%$ & $0.00 \%$ \\
\hline & & \multirow{2}{*}{\multicolumn{2}{|c|}{$\begin{array}{l}87.67 \\
13.15\end{array}$}} & & \multicolumn{2}{|r|}{105.07} & \multicolumn{2}{|r|}{$19.85 \%$} \\
\hline Profit 15\% & & & & & \multicolumn{2}{|r|}{15.76} & \multicolumn{2}{|r|}{$19.85 \%$} \\
\hline Price & & \multicolumn{2}{|r|}{100.82} & & \multicolumn{2}{|r|}{120.83} & \multicolumn{2}{|r|}{$19.85 \%$} \\
\hline
\end{tabular}


М. Поткани, Л.Крайчірова, М.Гітка, С. Лорінцова. Інновації методології розрахунків відповідно до змінених розмірними вимогами до окремої продукції

From the results (Table 5) we can conclude following. Product price determined in dynamic calculation methods is at the level of $120.83 €$, what is in comparison with absorption costing lower by $18 \%(142.96 €)$. This change is caused by adjusting of overheads rates, which in essence respects their variable and fixed part of ratio. This calculation offers more exact information for management at the decision - making tasks.

If we know the value of VC, we can calculate the level of contribution margin. Fibírová, Šoljaková and Wagner [31] say that the absolute amount of profit depends on the absolute contribution margin. That is currently represented by relation of the difference between price and VC (Table 7). For relevant results for decision making presented by retrograde calculation formula, we need to ensure the stability of production program. There should be no frequent changes in product structure. Similarly, there should be no often changes in amount of FC and VC. Potkány [32] is also dealing with the issue of contribution margins.

Table 6 - Changes in the CM value (authors' development)

\begin{tabular}{|l|r|r|r|r|r|r|}
\hline \multirow{2}{*}{} & \multicolumn{2}{|c|}{ Initial dimensions of single bed } & \multicolumn{3}{|c|}{ Enlarged dimensions of single bed } \\
\cline { 2 - 7 } & \multicolumn{1}{|c|}{$\boldsymbol{\%}$} & \multicolumn{1}{c|}{$\%$} & Original price (€) & \multicolumn{1}{c|}{ Increased price (€) } & $\%$ \\
\hline Price & 100.82 & 100.00 & 100.82 & 100.00 & 120.83 & 100.00 \\
\hline - VC & 41.46 & 41.13 & 58.86 & 58.38 & 58.86 & 48.71 \\
\hline = Contribution margin & 59.36 & 58.87 & 41.96 & 41.62 & 61.97 & 51.29 \\
\hline
\end{tabular}

Based on the results it is possible to state, that the value of the contribution margin by enlarged furniture dimensions and increased price is positive (61.97€). For the company that is positive information, because from each $1 €$ of sales almost $0.513 €$ can be used to cover the fixed cost and to make profit. But if the price of single bed stays the same even after the change (100.82 $€$ ), for company it will remain 0.416 $€$ to cover the fixed cost and to make profit from the $1 €$ of its sales. Absolute value of CM has essential influence to profit making potential. It is possible to reach profit only after that we reach level of costs, which cover FC in CM. This is the basic principle of BEA (Break-even analysis). Macík [18], Potkány and Krajčírová [33] were dealing in their works with this issue. The traditional type calculation (Table 8) and variable costing understand profit/loss differently. For practical explanation we can consider the hypothetical increase of production to $10,000-20,000$ pcs.

Table 7 - Single bed price quotation at the level of total costs (authors' development)

\begin{tabular}{|l|r|r|r|r|}
\hline & $\mathbf{1} \mathbf{p c}$ & $\mathbf{1 0 , 0 0 0}$ pcs & $\mathbf{1 5 , 0 0 0}$ pcs & \multicolumn{1}{|c|}{$\mathbf{2 0 , 0 0 0}$ pcs } \\
\hline Revenues & 120.83 & $1,208,300$ & $1,812,450$ & $2,416,600$ \\
\hline - Costs & 105.07 & $1,050,700$ & $1,576,050$ & $2,101,400$ \\
\hline = Profit & 15.76 & 157,600 & 236,400 & 315,200 \\
\hline
\end{tabular}

The traditional approach sees profit/loss as the difference between sales and costs. The variable costing separates fixed and variable cost components. The calculation of profit/loss includes VC and it understands FC as a whole for given period for whole company or its part. For calculated products are thus allocated only VC, which are composes by direct costs and variable overheads.

Table 8 - Variable costing (authors' development)

\begin{tabular}{|l|r|r|r|r|}
\hline & \multicolumn{1}{|c|}{$\mathbf{1}$ pc } & $\mathbf{1 0 , 0 0 0}$ pcs & $\mathbf{1 5 , 0 0 0}$ pcs & $\mathbf{2 0 , 0 0 0}$ pcs \\
\hline Revenues & 120.83 & $1,208,300$ & $1,812,450$ & $2,416,600$ \\
\hline - VC & 58.86 & 588,600 & 882,900 & $1,177,200$ \\
\hline = Contribution margin & 61.97 & 619,700 & 929,550 & $1,239,400$ \\
\hline - FC & \multicolumn{4}{|c|}{344,150} \\
\hline = Profit & & 275,550 & 585,400 & 895,250 \\
\hline
\end{tabular}

According to Macík [18] variable costing is applicable to solve different strategic system problems, 
such as determination of the order products profitability, determination of minimum selling price limit, choosing between production or cooperation. With the same issue Novák, et al. [34] and Sedliačiková, et al. [35] were dealing in their works.

From the above we can conclude, that by the cost items increasing the company, if it wants to achieve same level of Return on Costs, or same level of contribution margin, has to increase price of original product $(120.83 €)$. Comparing with the original price it is increase of more than $19.23 \%$ (Table 5). This can cause problems for company at the customer side in the form of reduced interest in product. The given situation can then be reflected to reduction in revenues, lower sales and problems related. The initial general calculation formula expanded by fixed and variable cost component breakdown contributes to more opportunities for company in resolving various decision-making tasks [36]. For company it provides broader information base for market orientation.

Conclusions and directions of further researches. As it can be seen from our previous studies of the dimensional characteristics of the current male Slovak population, it can be clearly stated that there has been a positive secular trend. We anticipate that this situation was due to better nutrition, better psychosocial factors and socio-economic conditions in which today's population grew. This trend will continue in a lesser extent. Since the values of the quantile characteristics of the anthropometric features are used to create ergonomic, hygienic and design standards in the area of furniture, it is necessary to reassess the suitability of the current standard dimensions of a single bed, therefore it is necessary to update the calculation formula when pricing the bed furniture [37]. Currently, standardized dimensions of single bed are $200 \times 90 \mathrm{~cm}$ or $200 \times 100 \mathrm{~cm}$. Therefore, it is clear that the dimensions are insufficient with the respect to the secular trend of anthropometric human development. Today, a man needs a minimum bed area of $220.5 \times 102.3 \mathrm{~cm}$, at a bed height of $45.7 \mathrm{~cm}$ (Table 2) for comfort and health. A good and comfortable bed should be longer than its user at least $20 \mathrm{~cm}$. As the secular trend is visible not only in our country but also in the world, it is necessary to revise the standards outdated under which furniture is produced currently in our country. After the updating, it is necessary to start looking at adjustments of calculation formula when pricing the bed furniture in furniture companies as the increase in dimensions will be reflected fundamentally in the product price. Economic damage may occur in the company, if the employees of the economic department do not deal with this problem.

Designing all kinds of furniture (for example bed, seat, cabinet, multipurpose, table and supplementary furniture) must be in direct relationship to the size and weight of the current population as well as the future population. Anthropological and ergonomic requirements are crucial in many ways in terms of shape, dimensions and the quality of furniture and materials used [38]. Based on our findings, we can state that currently individual parameters of bed furniture are not in compliance with the standards which means that the length, width and height of bed furniture does not meet the recommended ergonomic dimensions for the needs of today's population. Since the minimum bed dimensions for the current population exceed the European standardized dimensions, it is necessary to start looking at their modification. Modification of standard dimensions requires interdisciplinary collaboration between designers, anthropologists, ergonomists and health professionals. Only such a multidisciplinary approach can bring results in the production of healthy furniture that would not threaten the development of our population. At the same time, we recommend revising the outdated standards of dimensions that are currently used when making furniture. After updating, we recommend to deal with adjustments of calculation formula when pricing the bed furniture.

Our review of available scientific proposals for innovative calculation methodology proved the need for potential of concept of the variable costing at the base of cost classification to variable and fixed items according to capacity using. The practical imperfections of the information provided in the absorption costing system and its general rigidities was the reason of the application selected methodology. The authors proposed an alternative for calculation methodology by the determination of overheads rates and delimitation individual level of contribution margin. The findings presented can be used in the process of the anthropometric dimensions changing of many furniture types, but in the trend concept of its pricing, too. The proposal presented is innovative from the point of the incorporation of the secular trend of 
changes in the size of the adult population and also in the potential of using the principles of dynamic variable calculation in practice in the process of strategic and operational management. Owing to the fact that most bed furniture is manufactured according to standard furniture dimensions, we suggest revising them as well. It is therefore necessary to revise basic standards, which will include changes in their length and width dimensions, as well as an increase in direct cost consumption. Based on our findings, it can be said that these changes will also be reflected in a price change that in our case has increased by $20 \%$, but with a non-profitability level of $15 \%$ Return on Sales.

1. Cole, T.J. (2000). Secular trends in growth. The Proceedings of the Nutrition Society, 59, 317-324.

2. Cole, T.J. (2003). The secular trend in human physical growth: a biological view. Economics and Human Biology, 1, 161-168.

3. Chuan, T.K., Hartono, M., \& Kumar, N. (2010). Anthropometry of the Singaporean and Indonesian populations. International Journal of Industrial Ergonomics, 40, 757-766.

4. Loesch, D.Z., Stokes, K., \& Huggins, R.M. (2000). Secular trend in height and weight of Australian children and adolescents. American Journal of Physical Antropology, 111, 545-556.

5. Hajn, V. (2003). Antropologie I [Anthropology I]. Olomouc: Univerzita Palackého v Olomouci [in Czech].

6. Vignerová, J., Brabec, M., \& Bláha, P. (2006). Two centuries of growth among Czech children and youth. Economics \& Human Biology, 4, 237-252.

7. Jelačić, D., Greger, K., \& Grladinović, T. (2002). Research on anthropometric characteristics of high school students and ergonomic characteristics of high school furniture. Drvna Industrija, 53, 99-106.

8. Jirkovský, D. (2003). Tělesná výška a hmotnost mladých mužů vo věku $18-25$ let v druhé polovině 20 . století [Body height and weight of young men aged 18-25 in the second half of the 20th century]. Vojenské Zdravotnícke Listy - Military Medical Sheets, 72 [in Czech].

9. Vignerová, H. (2005). Dlouhodobé změny tělesných rozměrů českých dětí [Long-term changes in the physical dimensions of Czech children]. Stolársky Magazín - Stolar Magazine, 6, 46-47 [in Czech].

10. Hanson, L., Sperling, L., Gard, G., Ipsen S., \& Vergara, C.O. (2009). Swedish anthropometrics for product and workplace design. Applied Ergonomics, 40, 797-806.

11. Hitka, M., \& Hajduková, A. (2013). Antropometrická optimalizácia rozmerov lôžkového nábytku [Anthropometric optimization of bed furniture dimensions]. Acta Facultatis Xylologiae Zvolen, 55, 101-109 [in Slovak].

12. Barroso, M.P., Arezes, P.M., Da Costa, L.G., \& Miguel, A. (2005). Anthropometric study of Portuguese workers. International Journal of Industrial Ergonomics, 35, 401-410.

13. Klement, I., \& Matušková, M. (2008). Zmeny vybraných mechanických vlastností smrekového dreva pri vysokoteplotnom sušení [Changes in selected mechanical properties of spruce wood in high temperature drying]. Acta Facultatis Xylologiae, 50, 1525 [in Slovak].

14. Kivader, M., \& Klement, I. (2012). Determination of moisture content in spruce wood during high temperature drying process. Acta Facultatis Xylologiae, 54, 25-32

15. Teplická, K., Čulková, K., \& Manová, E. (2012). Using of operation analysis models in selected industrial firm. Acta Montanistica Slovaca, 17, 151-157.

16. Myšková, R. (2005). Metodika hodnocení spokojenosti pracovníků [Methodology of employee satisfaction assessment]. E\&M Economics and Management, 8, 84-97 [in Czech].

17. Kucharčíková, A., Tokarčíková, E., Klučka, J., \& Konušíková, J. (2015). Foreign direct investment: Impact on sustainable development in regions of Slovak Republic. Journal of Security and Sustainability Issues, 5, 59-71.

18. Macík, K. (2008). Kalkulace a rozpočetnictvi [Calculation and budgeting]. Praha: Nakladatelství ČVUT [in Czech]

19. Popesko, B. (2009). Moderni metody ř̌zeni nákladủ. Jak dosáhnout efektivního vynakládaní nákladů a jejich snížení [Modern Cost Management Methods. How to Efficiently Cost and Reduce Costs]. Praha: Grada Publishing [in Czech].

20. Poniščiaková, O. (2010). Náklady a kalkulácie v manažérskom účtovníctve [Costs and Costs in Managerial Accounting]. Bratislava: Iura Edition [in Slovak].

21. Lazar, J. (2012). Manažerské účetnictví a controlling [Managerial accounting and controlling]. Praha: Grada Publishing [in Czech].

22. Müller, I. (2004). Současný člověk a zdravý nábytek - II [Present Man and Healthy Furniture - II]. Stolársky Magazín Stolar Magazine, 5, 64 [in Czech]

23. Hajdu, Z., Andrejkovič, M., \& Mura, L. (2014). Utilizing experiments designed results during error identification and improvement of business processes. Acta Polytechnica Hungarica, 11, 149-166.

24. Bolstad, G., Benum, B., \& Rokne, A. (2001). Anthropometry of Norwegian light industry and office workers. Applied Ergonomics, 32, 239-246.

25. Kováč, J., \& Szombathyová, E. (2010). Ergonómia [Ergonomics]. Košice: Technická univerzita v Košiciach [in Slovak].

26. Rubínová, D. (2006). Ergonomie [Ergonomics]. Brno: Vysoké učení technické v Brne [in Czech].

27. Poštúlková, L'. (2004). Typológia zariad'ovacích prvkov. Človek - priestor - nábytok [Typology of fittings. Man - space furniture]. Zvolen: TU vo Zvolene [in Slovak].

28. STN EN 547-3 + A1 „Bezpečnost' strojov. Rozmery ludského tela. Čast' 3: Antropometrické údaje“ [Safety of machinery. 
Dimensions of the human body. Part 3: Anthropometric data] [in Slovak].

29. Scholleová, H. (2012). Ekonomické a finanční řizení pro neekonomy [Economic and Financial Management for NonEconomists]. Praha: Grada Publishing [in Czech].

30. Synek, M., et al. (2007). Manažerská ekonomika [Managerial Economics]. Praha: Grada Publishing [in Slovak].

31. Fibírová, J., Šoljaková, L., \& Wagner, J. (2007). Nákladové a manažerské účetnictví [Cost accounting and accounting]. Praha: ASPI [in Czech].

32. Potkány, M. (2005). System for establishing intradepartmental prices in Slovak wood processing industry. Drvna Industrija, 56, $177-188$.

33. Potkány, M., \& Krajčirová, L. (2015). Quantification of the volume of products to achieve the break-even point and desired profit in non-homogeneous production. Procedia Economics and Finance, 26, 194-201.

34. Novák, P., Papadaki, S., Hrabec, D., \& Popesko, B. (2016). Comparison of managerial implications for utilization of variable costing and throughput accounting methods. Journal of Applied Engineering Science, 14, 351-360.

35. Sedliačiková, M., Šatanová, A., \& Foltínová, A. (2012). Financial controlling in theory and praxis of small and medium-size enterprises. Journal of Economics, 60, 949-966.

36. Zámečník, R. (2016). The qualitative indicators in human resource accounting. Marketing and Management of Innovations, 4, 325-341.

37. Hrovatin, J., Prekrat, S., Oblak, L., \& Ravnik, D. (2015). Ergonomic suitability of kitchen furniture regarding height accessibility. Collegium Antropologicum, 39, 185-191.

38. Nedeliaková, E., Sekulová, J., \& Nedeliak, I. (2015). Application of dynamic models as a new trend in quality management. Procedia Economics and Finance, 34, 180-186.

M. Поткани, PhD, доцент кафедри економіки бізнесу, факультет лісових наук і технологій, Технічний університет в Зволені (м. Зволен, Словаччина);

Л. Крайчірова, PhD, асистент кафедри економіки бізнесу, факультет лісових наук і технологій, Технічний університет в Зволені (м. Зволен, Словаччина);

M. Гітка, PhD, доцент кафедри економіки бізнесу, факультет лісових наук і технологій, Технічний університет в Зволені (м. Зволен, Словаччина);

С. Лорінцова, PhD, асистент кафедри економіки бізнесу, факультет лісових наук і технологій, Технічний університет в Зволені (м. Зволен, Словаччина)

Інновації методології розрахунків відповідно до змінених розмірними вимогами до окремої продукції

Основна мета статті - викласти авторський інноваційний підхід до оптимізації методології розрахунку в умовах конкретного виробниитва меблів - односпальних ліжок. Запропонований підхід заснований на результатах фактичних досліджень антропометричних вимірювань словацького дорослого населення, які вказують на тенденцію змін і наступні змінені вимоги до обсягу продукиії. Наш огляд доступних наукових пропозицій щодо інноваційної методології розрахунку довів необхідність потенційної концепції змінної калькуляції в основі класифікації витрат для змінних і фіксованих позицій залежно від використання потужності. Практичні недоліки інформації, наданої в системі калькуляції витрат та ї̈ загальної жорсткості, були причиною застосування обраної методології. Автори запропонували альтернативу методології розрахунку шляхом визначення ставок накладних витрат і розмежування індивідуального рівня вкладу.

Ключові слова: розрахунок, маржа вкладів, розміри меблів для спальні, ергономіка, світські тенденції, інновації.

M. Потканы, PhD, доцент кафедры экономики бизнеса, факультет лесных наук и технологий, Технический университет в Зволене (г. Зволен, Словацкая Республика);

Л. Крайчирова, $\mathrm{PhD}$, ассистент кафедры экономики бизнеса, факультет лесных наук и технологий, Технический университет в Зволене (г. Зволен, Словацкая Республика);

M. Гитка, PhD, доцент кафедры экономики бизнеса, факультет лесных наук и технологий, Технический университет в Зволене (г. Зволен, Словацкая Республика);

C. Лоринцова, PhD, ассистент кафедры экономики бизнеса, факультет лесных наук и технологий, Технический университет в Зволене (г. Зволен, Словацкая Республика)

Инновации методологии расчетов в соответствии с измененными размерными требованиями котдельной продукции

Основная цель статьи - представить авторский инновационный подход к оптимизации методологии расчета в условиях конкретного производства мебели - односпальных кроватей. Предложеный подход основан на результатах фрактических исследований антропометрических измерений словацкого взрослого населения, которые указывают на тенденцию изменений и следующие измененные требования к размеру продукции. Наш обзор доступных научных предложений по инновационной методологии расчета доказал необходимость потенциальной концепции переменной калькуляции в основе классификации затрат для переменных и фиксированных позиций в зависимости от использования мощности. Практические недостатки инфрормации, предоставленной в системе калькуляции затрат и ее общей жесткости, были причиной применения выбранной методологии. Авторы предложили альтернативу методологии расчета путем определения ставок накладных расходов и разграничения индивидуального уровня вклада.

Ключевые слова: расчет, маржа вкладов, размеры мебели для спальни, эргономика, светские тенденции, инновации.

Отримано 04.05.2017 p. 